\title{
Exogenous Hydrogen Sulfide Protects against Doxorubicin-Induced Inflammation and Cytotoxicity by Inhibiting p38MAPK/ NFkB Pathway in H9c2 Cardiac Cells
}

\author{
Runmin Guo ${ }^{\mathrm{a}, \mathrm{e}}$ Keng Wu $\mathrm{W}^{\mathrm{a}, \mathrm{e}}$ Jingfu Chen ${ }^{\mathrm{a}}$ Liqiu Mo $\mathrm{M}^{\mathrm{b}}$ Xiaoxiao Hua ${ }^{\mathrm{b}}$ \\ Dongdan Zheng ${ }^{c}$ Peixi Chen ${ }^{d}$ Gang Chen ${ }^{c}$ Wenming $X^{c}{ }^{c}$ Jianqiang Feng ${ }^{d}$
}

\begin{abstract}
aDepartment of Cardiology, The Affiliated Hospital, Guangdong Medical College, Zhanjiang, ${ }^{b}$ Department of Anesthesiology, 'Department of Internal Medicine, Huangpu Division of the First Affiliated Hospital; 'Department of Physiology, Zhongshan School of Medicine, Sun Yat-sen University,

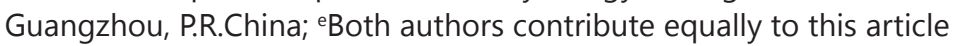

\section{Key Words}

Hydrogen sulfide - Doxorubicin - Cardiotoxicity • Inflammation • p38 mitogen-activated protein kinases $\cdot$ Nuclear factor- $\mathrm{kB}$

\footnotetext{
Abstract

Background/Aim:We have demonstrated that exogenous hydrogen sulfide $\left(\mathrm{H}_{2} \mathrm{~S}\right)$ protects $\mathrm{H} 9 \mathrm{c} 2$ cardiac cells against the doxorubicin (DOX)-induced injuries by inhibiting p38 mitogenactivated protein kinase (MAPK) pathway and that the p38 MAPK/nuclear factor-KB (NF-KB) pathway is involved in the DOX-induced inflammatory response and cytotoxicity. The present study attempts to test the hypothesis that exogenous $\mathrm{H}_{2} \mathrm{~S}$ might protect cardiomyocytes against the DOX-induced inflammation and cytotoxicity through inhibiting p38 MAPK/NFKB pathway. Methods: H9c2 cardiac cells were exposed to $5 \mu \mathrm{M}$ DOX for $24 \mathrm{~h}$ to establish a model of DOX cardiotoxicity. The cells were pretreated with NaHS( a donor of $\mathrm{H}_{2} \mathrm{~S}$ ) or other drugs before exposure to DOX. Cell viability was analyzed by cell counter kit 8 (CCK8), The expression of NF-kB p65 and inducible nitric oxide synthase (iNOS) was detected by Western blot assay. The levels of interleukin-1 $\beta$ (IL-1 $\beta$ ), IL- 6 and tumor necrosis factor- $\alpha$ (TNF- $\alpha$ ) were tested by enzyme-linked immunosorbent assay (ELISA). Results: Our findings demonstrated that pretreatment of $\mathrm{H} 9 \mathrm{c} 2$ cardiac cells with NaHS for 30 min before exposure to DOX markedly ameliorated the DOX-induced phosphorylation and nuclear translocation of NF-KB p65 subunit. Importantly, the pretreatment with NaHS significantly attenuated the p38 MAPK/NF-KB pathway-mediated inflammatory responses induced by DOX, as evidenced by decreases in the levels of IL-1 $\beta$, IL- 6 and TNF- $\alpha$. In addition, application of NaHS or IL-1 $\beta$ receptor antagonist (IL-1Ra) or PDTC (an inhibitor of NF-kB) attenuated the DOX-induced expression of iNOS and production of nitric oxide (NO), respectively. Furthermore, IL-1Ra also

Prof. Jianqiang Feng and Dr. Wenming Xu

Department of Physiology, Zhongshan School of Medicine, Sun Yat-sen University Guangzhou, 510080 (China);

and Department of Internal Medicine, Huangpu Division of the First Affiliated Hospital, Sun Yat-sen University, Guangzhou, 510080 (P.R.China)

E-Mail fengjq-sums@163.com and E-Mail xwm920018@163.com
} 
dramatically reduced the DOX-induced cytotoxicity and phosphorylation of NF- $\mathrm{kB}$ p65. The pretreatment of $\mathrm{H} 9 \mathrm{c} 2$ cells with $\mathrm{N}$-acetyl-L-cysteine (NAC), a scavenger of reactive oxygen species (ROS) prior to exposure to DOX depressed the phosphorylation of NF-KB p65 induced by DOX. Conclusion: The present study has demonstrated the new mechanistic evidence that exogenous $\mathrm{H}_{2} \mathrm{~S}$ attenuates the DOX-induced inflammation and cytotoxicity by inhibiting p38 MAPK/NF-KB pathway in $\mathrm{H} 9 \mathrm{c} 2$ cardiac cells. We also provide novel data that the interaction between NF-KB pathway and IL-1 $\beta$ is important in the induction of DOX-induced inflammation and cytotoxicity in $\mathrm{H} 9 \mathrm{c} 2$ cardiac cells.

\section{Introduction}

Clinically, doxorubicin (DOX) is one of the most widely used anticancer drugs [1, 2], due to its potent therapeutic effects on a variety of cancer, including leukemias, lymophomas, softtissue sarcomas, and solid tumors [3]. Unfortunately, its clinical use is limited by a dose-related acute and chronic cardiotoxicity $[4,5]$. The mechanisms of DOX-induced cardiotoxicity are not fully understood, but accumulating evidence indicates that oxidative stress and cardiac inflammation are involved [6-10]. For this reason, 3-hydroxy-3-methylglutaryl coenzyme A (HMG-CoA-reductase) inhibitor, also known as statin, which has anti-inflammatory and antioxidative effects, has been used to attenuate the cardiotoxicity of DOX in mice [9]. In addition, the previous studies showed that both attenuated cardiac cytokine activation and lipid peroxidation are important for the improved left ventricular (LV) function in a mouse model of DOX-induced cardiotoxicity $[8,11]$.

Recently, the signal transduction pathway that links the DOX-induced oxidatvie stress and inflammation in cardiac tissue is a topic of strong current interest. Guo et al. have demonstrated that the activation of p38 mitogen-activated protein kinase (MAPK), one of the members of MAPK family, which has been shown to participate in cardiomyocyte apoptosis and cardiac pathologies [12, 13], contributes to the DOX-induced injuries, including cytotoxicity, apoptosis, mitochondrial damage and oxidative stress in H9c2 cardiac cells [10]. We also more recently showed that the p38 MAPK/nuclear factor $\kappa \mathrm{B}(\mathrm{NF}-\kappa \mathrm{B})$ pathway is implicated in the DOX-induced inflammatory response, as demonstrated by increases in the levels of interleukin-1 $\beta$ (IL-1 $\beta$ ), IL- 6 and tumor necrosis factor- $\alpha$ (TNF- $\alpha$ ) production [14]. Based on the above studies, it is reasonable to speculate that the molecules with inhibitory effect on the activation of $\mathrm{p} 38 \mathrm{MAPK} / \mathrm{NF}-\kappa \mathrm{B}$ pathway might be beneficial for improvement of the DOX-induced cardiomyocyte inflammation. One of the potential candidate molecules is hydrogen sulfide $\left(\mathrm{H}_{2} \mathrm{~S}\right)$.

$\mathrm{H}_{2} \mathrm{~S}$, is colorless gas with strong odor of rotten eggs, has been recognized as the third endogenous gasotransmitter signaling molecule alongside with nitric oxide (NO) and carbon monoxide (CO) $[15,16]$. Increasing evidence has shown that $\mathrm{H}_{2} \mathrm{~S}$ is an important cardioprotective agent $[14,17,18,19,20]$. Chronic $\mathrm{H}_{2} \mathrm{~S}$ treatment enhances survival and prevents from ischemic-induced heart failure [21]. More recently, we have demonstrated the cardioprotective effect of exogenous $\mathrm{H}_{2} \mathrm{~S}$ against chemical hypoxia-induced insult by inhibiting oxidative stress and enhancing heat shock protein 90 (HSP90) expression [19, 20]. Notably, the effects of $\mathrm{H}_{2} \mathrm{~S}$ on the DOX-induced cardiotoxicity have attracted attention due to its antioxidant and anti-inflammatory effects $[14,18,19,20,22,23,24]$. The findings from in vivo and in vitro studies showed that DOX markedly reduces the endogenous $\mathrm{H}_{2} \mathrm{~S}$ production in myocardium [25] or cardiomyocytes [7] and that exogenous $\mathrm{H}_{2} \mathrm{~S}$ significantly improves the DOX-induced cardiac dysfunction [25] or cardiomyocyte injury [7] by its antioxidant effect. Furthermore, exogenous $\mathrm{H}_{2} \mathrm{~S}$ attenuates the chemical hypoxia-induced inflammatory response in HaCaT cells [22] or PC12 cells [23] and ameliorates lipopolysaccharide (LPS)triggered inflammation in microglia and astrocytes [24]. However, to our knowledge, no 
work has been focused on the protective effect of exogenous $\mathrm{H}_{2} \mathrm{~S}$ against the DOX-induced inflammation and its mechanisms. Based on our recent studies [7, 10, 22, 23] and others $[24,25]$, the present study aimed to investigate whether exogenous $\mathrm{H}_{2} \mathrm{~S}$ pretreatment can produce anti-inflammatory effects and explore the potential relation of these effects to inhibition of p38 MAPK/NF-kB pathway in the DOX-treated H9c2 cardiac cells [7].

\section{Materials and Methods}

\section{Reagents}

Sodium hydrogen sulfide (NaHS), SB203580, doxorubicin (DOX), N-(1-naphthylethylenediamine) dihydrochloride, sulfanilamide, L-canavanine(L-Can) and pyrrolidine dithiocarbamate (PDTC) were purchased from Sigma-Aldrich (St. Louis, MO, USA). The Cell Counter Kit-8 (CCK-8) was purchased from Dojindo Lab (Japan). The enzyme linked immunosorbent assay (ELISA) kits for IL-1 $\beta$, IL-6 and TNF- $\alpha$ were purchased from Boster biotech (Wuhan, People's Republic of China). Interleukin-1 receptor antagonist (IL$1 \mathrm{Ra}$ ) was purchased from ProSpec (Ness-Ziona, Israel). DMEM-F12 medium and fetal bovine serum were purchased from Gibco-BRL. H9c2 cells were obtained from the Sun Yat-sen University Experimental Animal Center.

\section{Cell culture and treatments}

$\mathrm{H} 9 \mathrm{c} 2$ cardiac cells were cultured in DMEM-F12 medium supplemented with $10 \% \mathrm{FBS}$ at $37{ }^{\circ} \mathrm{C}$ under an atmosphere of $5 \% \mathrm{CO}_{2}$. To explore the protective effects of $\mathrm{H}_{2} \mathrm{~S}$ on the DOX-induced injury, cells were pretreated with $400 \mu \mathrm{M}$ NaHS (a well-known $\mathrm{H}_{2} \mathrm{~S}$ donor) for 30 min prior to DOX treatment. To further determine whether the anti-inflammatory effects of $\mathrm{H}_{2} \mathrm{~S}$ were associated with the inhibition of p38 MAPK/ NF- $\mathrm{BB}$ pathway activity, H9c2 cells were pretreated with either SB203580 (a selective inhibitor of p38 MAPK) or PDTC (a specific inhibitor of NF- $\kappa B$ ) or small interfering RNA against p38 (Si-p38) prior to DOX treatment.

\section{Cell viability assay}

After H9c2 cells were cultured in 96-well plates and received different treatments, $10 \mu \mathrm{l}$ CCK-8 solution was added to each well at a 1/10 dilution, followed by a further $2 \mathrm{~h}$ incubation in the incubator. Absorbance was measured at $450 \mathrm{~nm}$ with a microplate reader (Multiskan MK3 Microplate reader, Thermo Fisher Scientific Inc, USA). The mean optical density (OD) of five wells in the indicated groups was used to calculate the percentage of cell viability according to the formula below:

Percentage of cell viability $=$ OD treatment group $/$ DD control group $\times 100 \%$. Experiments were repeated 3 times.

\section{ELISA for detection of IL-1 $\beta, I L-6$ and TNF- $\alpha$ in culture supernatant}

H9c2 cells were cultured in 96-well plates. After the indicated treatments, levels of IL-1 $\beta$, IL-6 and TNF- $\alpha$ in the culture media were measured by enzyme-linked immunosorbent assay (ELISA) according to the manufacturer's instruction. The experiments were performed at least 5 times.

\section{NO Determination in Culture Supernatant}

Nitrite, an indicator of the production of NO, was measured in the culture supernatant using a commercial kit. Briefly, $50 \mu \mathrm{l}$ aliquots of cell culture medium from each dish were collected and mixed with $100 \mu \mathrm{l}$ of Griess reagent $(50 \mu \mathrm{l}$ of $1 \%$ sulfanilamide+ $50 \mu \mathrm{l}$ of $0.1 \%$ naphthylethylenediamine dihydrochloride in $2.5 \% \mathrm{H}_{3} \mathrm{PD}_{4}$ ) in a 96-well microtiter plate.The absorbance of $\mathrm{NO}_{2}^{-}$was read at $520 \mathrm{~nm}$ using a plate reader.

\section{Extraction of cytoplasmic and nuclear proteins}

After the indicated treatments, H9c2 cells were harvested. Cellular proteins in cytoplasm and nucleus from H9c2 cells were isolated by NE-PER Nuclear and Cytoplasmic Extraction Kit according to the manufacturer's protocol (Thermo Scientific). Briefly, after washing for three times with cold phosphatebuffered saline (PBS), cells were treated with cytoplasmic protein extraction buffer to isolate cytoplasm 
fraction proteins. Then, the nuclear proteins were extracted by adding nuclear protein extraction buffer. Cytoplasmic and nuclear protein extracts were used for Western blot analysis.

\section{Western blot assay}

After the indicated treatments, H9c2 cells were harvested and lysed, and the homogenate was centrifuged at $12,000 \mathrm{rpm}$ for $10 \mathrm{~min}$ at $4{ }^{\circ} \mathrm{C}$. The total protein in the supernatant was quantitated with a BCA protein assay kit (Thermo Fisher Scientific Inc, Rockford, IL, USA). Total protein (30 $\mu$ g from each sample) was separated by $12 \%$ SDS-PAGE. The protein in the gel was transferred to a polyvinylidene difluoride (PVDF) membrane. The membrane was blocked with 5\% free-fat milk in TBS-T for $1 \mathrm{~h}$ at room temperature, and then incubated with primary antibodies specific to p65, p-p65 (1:4,000) (Cell Signaling Technology, Beverly, MA, USA)and iNOS (1:1,000) (Santa Cruz Biotechnology, CA, USA), or GAPDH with gentle agitation at $4{ }^{\circ} \mathrm{C}$ overnight and subsequently incubated with the secondary antibodies for $1.5 \mathrm{~h}$ at room temperature. Following three washes with TBS-T, membranes were developed using enhanced chemiluminescence and exposed to X-ray films. To quantify protein expression, the X-ray films were scanned and analyzed with ImageJ 1.410 software (National Institutes of Health, USA).

\section{Gene knockdown}

Small interfering RNA (Si-RNA) against rat p38 MAPK (NM-031020) was synthesized by GenePharma Co., Ltd (People's Republic of China). The Si-RNA of p38 (Si-p38) and random non-coding RNA (Si-NC) were transfected into H9c2 cells using Lipofectamine 2000, according to the manufacturer's instruction (Invitrogen, USA). Si-p38MAPK and Si-NC (50 nM) were incubated with the cells for $6 \mathrm{~h}$ in order to transfect into the cells. Efficiency of genetic silencing by Si-RNA was evaluated by western blot assay.

\section{Statistical analysis}

All data were presented as the mean \pm standard error (SE). Differences between groups were analyzed by one-way analysis of variance (ANOVA) with SPSS 13.0 (Chicago, IL, USA). P<0.05 was considered to be significantly different.

\section{Results}

Exogenous $\mathrm{H}_{2}$ S attenuates DOX-induced activation of NF- $\mathrm{KB}$ p65 in $\mathrm{H} 9 \mathrm{c} 2$ cells

We firstly observed the effect of exogenous $\mathrm{H}_{2} \mathrm{~S}$ on changes of phosphorylated (p) NF- $\kappa B$ p65 (an essential step of NF- $\kappa B$ activation) induced by DOX, H9c2 cells were pretreated with $400 \mu \mathrm{M}$ NaHS (a donor of $\mathrm{H}_{2} \mathrm{~S}$ ) for $30 \mathrm{~min}$ prior to exposure to $5 \mu \mathrm{M}$ DOX for $90 \mathrm{~min}$ [10]. As shown in Fig. 1, exposure of H9c2 cells to DOX significantly enhanced the expression level of p-NF- $\kappa B$ p65. This increased expression of p-NF- $\kappa$ B p65 was reduced by NaHS pretreatment. $\mathrm{NaHS}$ at $400 \mu \mathrm{M}$ alone did not alter the basal expression level of p-NF- $\kappa \mathrm{B}$ p65 in H9c2 cells (Fig. $1 \mathrm{~A}$ and $\mathrm{B}$ ).

Next, we explored the effect of exogenous $\mathrm{H}_{2} \mathrm{~S}$ on the nuclear translocation of NF- $\kappa \mathrm{B}$ p65 subunit. As shown in Fig.1, NaHS pretreatment significantly ameliorated the DOX-induced nuclear translocation (Fig. $1 \mathrm{E}$ and F), with increasing amounts of NF- $\mathrm{kB}$ p65 in cytosol (Fig. $1 \mathrm{C}$ and D) and corresponding decreasing amounts in the nuclear extract (Fig. $1 \mathrm{E}$ and F). These results suggested that exogenous $\mathrm{H}_{2} \mathrm{~S}$ inhibits NF- $\kappa$ B activation by blocking DOXinduced phosphorylation and nuclear translocation of p65 subunit.

Exogenous $\mathrm{H}_{2} \mathrm{~S}$ suppresses DOX-induced production of pro-inflammatory cytokines by inhibiting p38 MAPK/NF- $\mathrm{B}$ B pathway in H9c2 cells

We have shown that exogenous $\mathrm{H}_{2} \mathrm{~S}$ depresses the stimulatory effect of DOX on phosphorylation of p38 MAPK [10] which enhances the DOX-induced activation of NF- $\mathrm{BB}$ p65 [14]. Combining with the above results (Fig. 1); it was suggested that exogenous $\mathrm{H}_{2} \mathrm{~S}$ can inhibit the activation of p38 MAPK/NF- $\kappa$ B pathway in the DOX-treated H9c2 cells. Based on these results, we further investigated the role of inhibiton of $\mathrm{p} 38 \mathrm{MAPK} / \mathrm{NF}-\kappa \mathrm{B}$ pathway in the protective effect of exogenous $\mathrm{H}_{2} \mathrm{~S}$ against DOX-induced inflammatory responses. 
Fig. 1. Exogenous $\mathrm{H}_{2} \mathrm{~S}$ reduces DOX-induced activation of NF- $\kappa$ B p65 in $\mathrm{H} 9 \mathrm{c} 2$ cells. H9c2 cells were exposed to $5 \mu \mathrm{M}$ DOX for 90 min in the absence or presence of pretreatment with $400 \mu \mathrm{M}$ NaHS for $30 \mathrm{~min}$ before exposure to DOX. Cytoplasm and nuclear extracts were extracted. The expression of NF-kB p65 was analyzed by Western blot analysis with anti-p65 antibody(A, C and E). (B), (D) and (F) The data in (A), (C) and (E) were quantified by densitometric analysis with ImageJ 1.410 software, respectively. Data are shown as the mean \pm SE (N $=3$ ). ${ }^{* *} \mathrm{P}<0.01$, compared with the control group; \#\# $\mathrm{P}<0.01$, compared with the DOX-treated group. Con, control, DOX, doxorubicin. t, total, Nuc, nuclear, Cyto, cytoplasm.

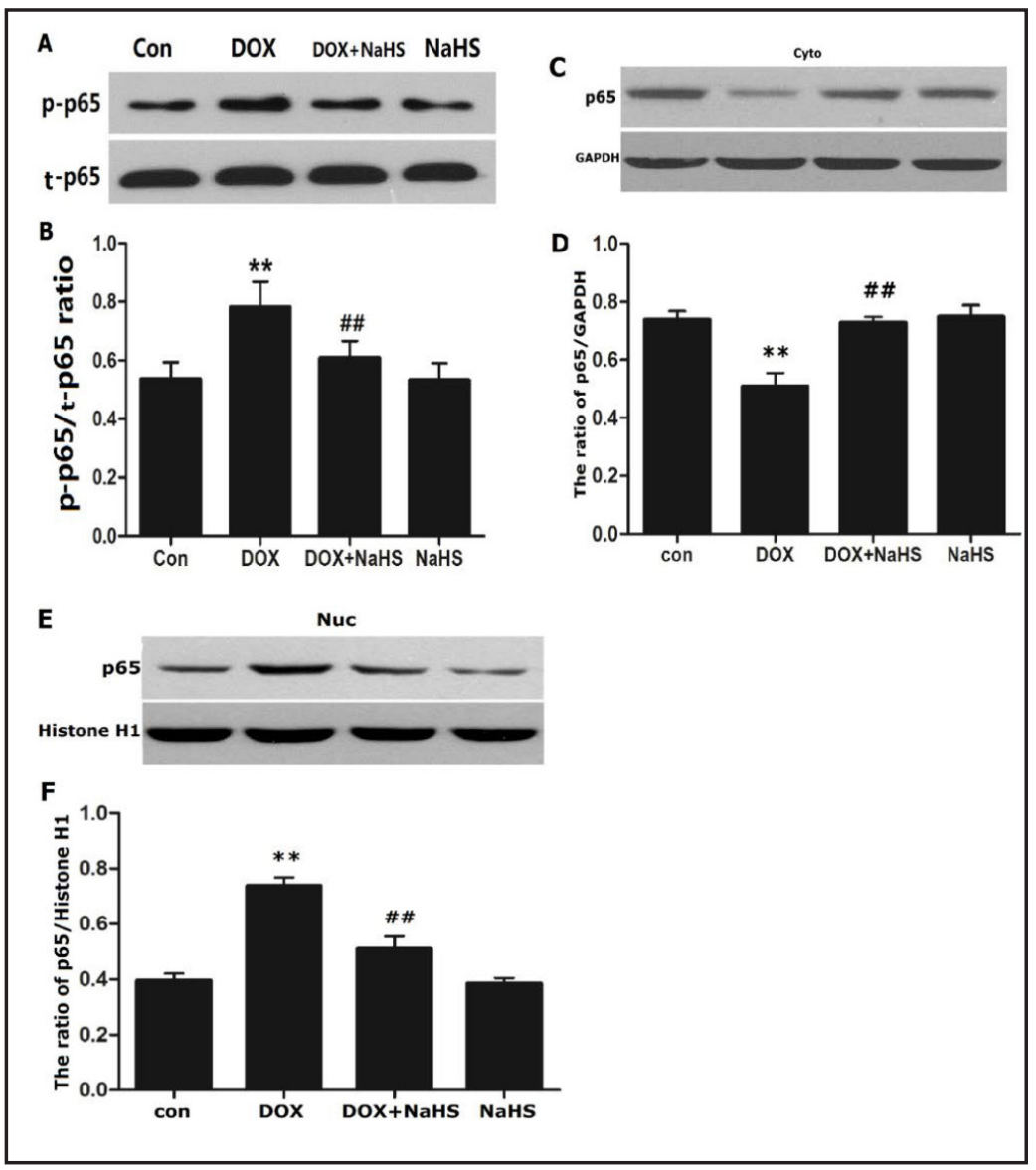

As shown in Fig. 2, after H9c2 cells were exposed to $5 \mu \mathrm{M}$ DOX for $24 \mathrm{~h}$, the levels of IL$1 \beta$ (Fig.2 A) , IL-6 (Fig. 2 B) and TNF- $\alpha$ (Fig. 2 C) were markedly increased, compared with the control group $(P<0.01)$, respectively. However, these increased levels of IL-1 $\beta$, IL- 6 and TNF- $\alpha$ by DOX were significantly ameliorated by pretreatment with $400 \mu \mathrm{M}$ NaHS for 30 min before exposure to DOX (Fig. 2), suggesting the inhibitory effect of exogenous $\mathrm{H}_{2} \mathrm{~S}$ on production of pro-inflammatory cytokines, including IL-1 $\beta$, IL- 6 and TNF- $\alpha$ induced by DOX.

Similarly, pretreatment of H9c2 cells with $3 \mu$ M SB203580, a selective inhibitor of p38 MAPK, for $60 \mathrm{~min}$ prior to exposure to $5 \mu \mathrm{M}$ DOX also depressed the enhanced production of IL-1 $\beta$, IL- 6 and TNF- $\alpha$ (Fig. 2A, B and C). To further demonstrate the roles of p38 MAPK in the DOX-induced production of pro-inflammatory cytokines, gene silencing experiments were performed. As shown in Fig. 2 D, genetic silencing of p38 MAPK by RNAi (Si-p38) attenuated the expression of p38 MAPK. Of note, after p38 MAPK was suppressed by Si-p38, the DOXinduced increased production of IL-1 $\beta$, IL- 6 and TNF- $\alpha$ was also alleviated (Fig. 2A, B and C). Co-incubation of H9c2 cells with random non-coding RNA(Si-NC) did not alter the DOXinduced production of pro-inflammatory cytokines(Fig. 2A, B and C).

Furthermore, pretreatment of the cells with $100 \mu \mathrm{M}$ PDTC, a specific inhibitor of NF- $\kappa B$, for 30 min before exposure to DOX dramatically blocked increase in production of IL-1 $\beta$, IL-6 and TNF- $\alpha$ (Fig. 2A, B and C).

Exogenous $\mathrm{H}_{2} \mathrm{~S}$, IL-1 $\beta$ receptors antagonist and PDTC depress iNOS/NO system in the DOXtreated H9c2 cells

Since iNOS and NO have been shown to be involved in the DOX cardiotoxicity $[26,27$, $28]$ and induced by pro-inflammatory cytokines(IL-1 $\beta$ and TNF- $\alpha$ ) $[29,30]$ and NF- $\mathrm{KB}$ [31], we observed the effect of exogenous $\mathrm{H}_{2} \mathrm{~S}$ on iNOS/NO system and the relationship between 


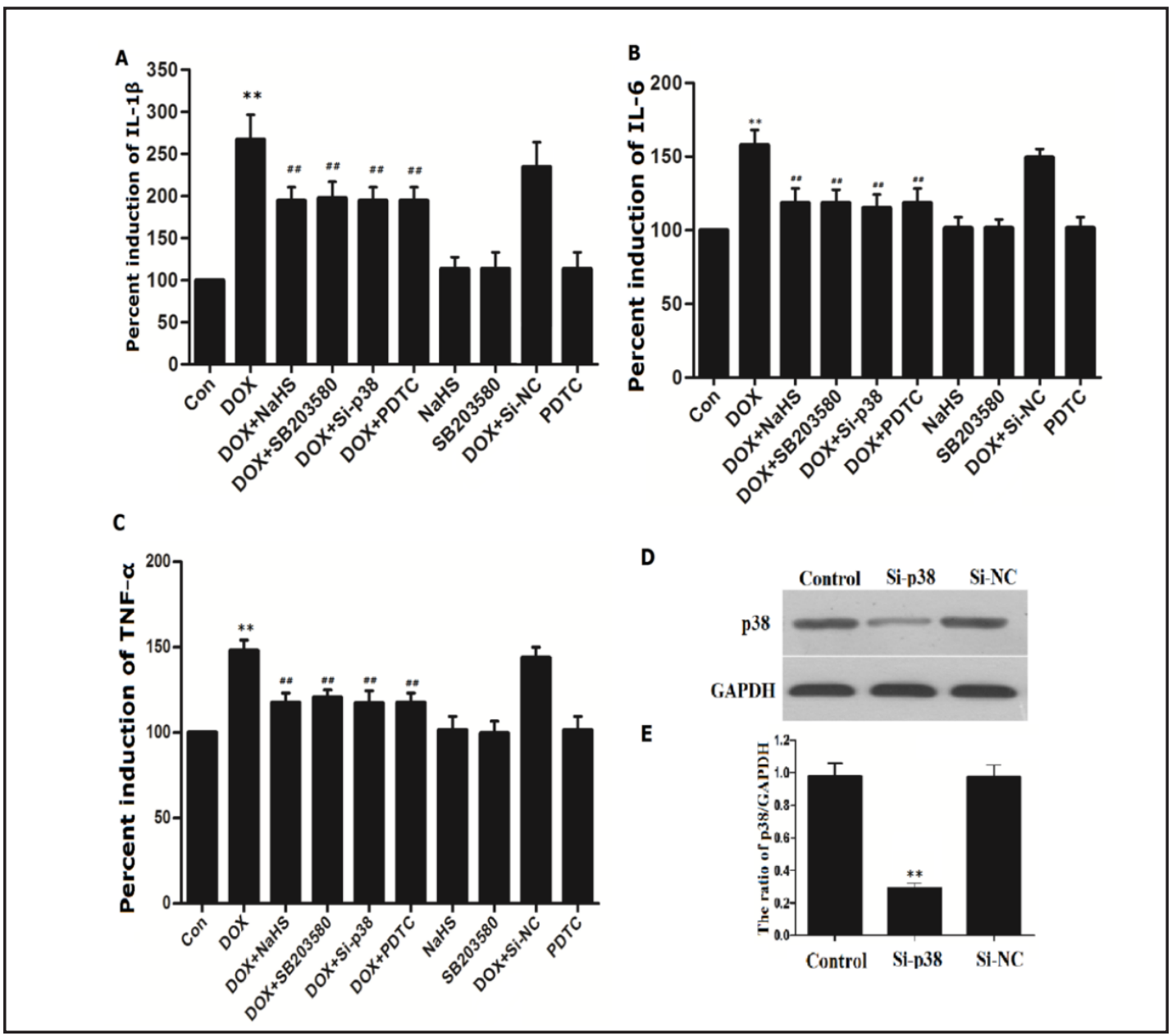

Fig. 2. Effects of different treatments on the DOX-induced production of IL-1 $\beta$, IL-6 and TNF- $\alpha$ in H9c2 cells. H9c2 cells were treated with $5 \mu \mathrm{M}$ DOX for $24 \mathrm{~h}$ in the absence or presence of pretreatment with either 400 $\mu \mathrm{M}$ NaHS or $100 \mu \mathrm{M}$ PDTC for $30 \mathrm{~min}$ or $3 \mu \mathrm{M}$ SB203580 for 60 min prior to exposure to DOX or co-incubation with Si-p38 for 6 h. ELISA was performed to measure the levels of IL-1 $\beta$ (A) ,IL-6 (B) and TNF- $\alpha(C)$ in cell supernatants. (D) and (E) H9c2 cells were co-cultured with Si-p38 MAPK or random non-coding RNA $(\mathrm{Si}-\mathrm{NC})$ at $50 \mathrm{nmol} / \mathrm{L}$ for $6 \mathrm{~h}(\mathrm{~N}=3)$. The data are presented as the mean $\pm \mathrm{SE}(\mathrm{N}=5) . * * \mathrm{P}<0.01$, compared with the control group; ${ }^{\# \# ~} \mathrm{P}<0.01$, compared with the DOX-treated group. SB203580, a selective inhibitor of p38 MAPK; PDTC, pyrrolidine dithiocarbamate; Si-p38, small interfering RNA against p38 MAPK.

IL-1 $\beta$ receptors and NF- $\kappa B$ and iNOS/NO system in the DOX-treated H9c2 cells. As shown in Fig. 3, exposure of the cells to $5 \mu \mathrm{M}$ DOX for $24 \mathrm{~h}$ markedly enhanced the expression of iNOS (Fig. 3A and B)and NO production (Fig. 3E). However, the increased expression of iNOS and NO production were reduced by pretreatment of the cells with $400 \mu \mathrm{M}$ NaHS for $30 \mathrm{~min}$ prior to exposure to DOX. Similarly, co-treatment of the cells with $20 \mathrm{ng} / \mathrm{ml} \mathrm{IL-1 \beta}$ receptor antagonist (IL-1Ra) and DOX for $24 \mathrm{~h}$ (Fig. 3A, B and E) or pretreatment with 100 $\mu \mathrm{M}$ PDTC for 30 min (Fig. 3C, D and E) before exposure to DOX also ameliorated increases in expression of iNOS and NO production induced by DOX. These findings suggested that exogenous $\mathrm{H}_{2} \mathrm{~S}$ inhibits iNOS/NO system and that IL- $1 \beta$ receptors and NF- $\kappa$ B are implicated in the expression of iNOS and NO production in the DOX-treated H9c2 cells. 
Fig. 3. Effects of different treatments on iNOS/NO system in the DOX-treated H9c2 cells. (A, B, C and D) The expression of iNOS was measured by Western blot assay and quantified by densitometric analysis with Image 1.410 software.(E) Nitrite, an indicator of the production of NO, was detected in the culture supernatant using a commercial kit. To explore the effects of exogenous $\mathrm{H}_{2} \mathrm{~S}$ and NF- $\kappa B$ on iNOS expression and NO production, H9c2 cells were pretreated with either 400 $\mu \mathrm{M}$ NaHS or $100 \mu \mathrm{M}$ PDTC for $30 \mathrm{~min}$ before exposure to DOX for $24 \mathrm{~h}$. To investigate the role of IL-1 $\beta$

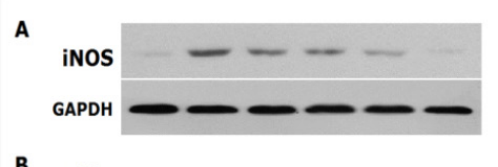

B
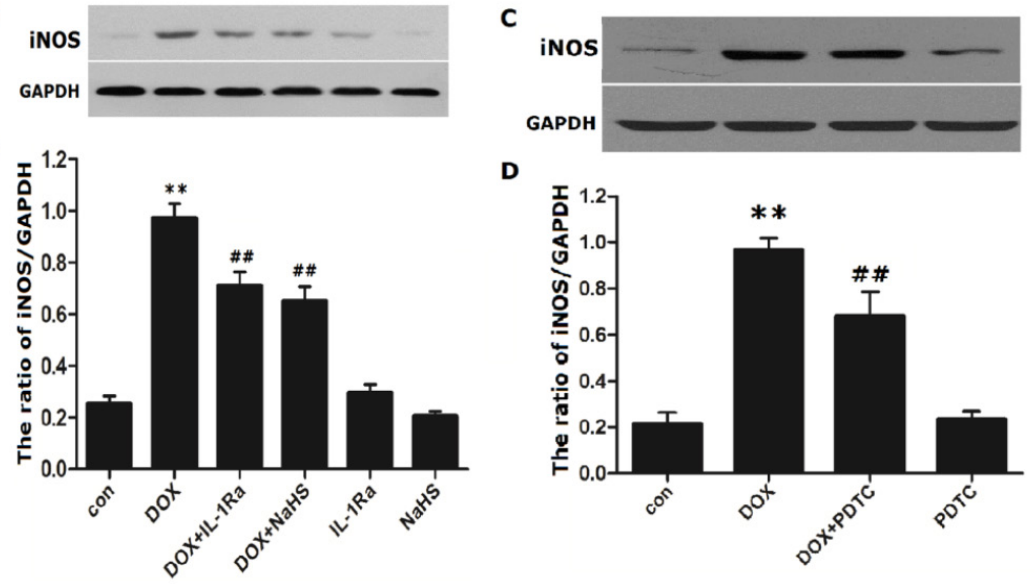

D

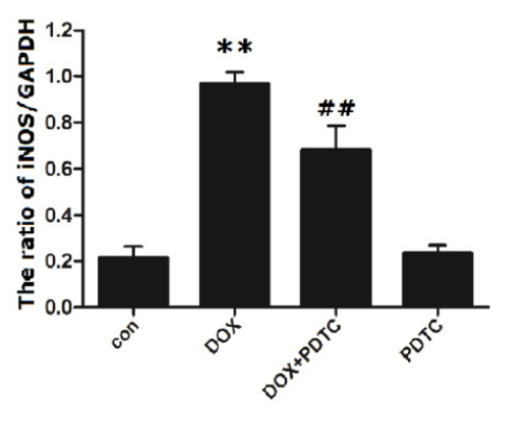

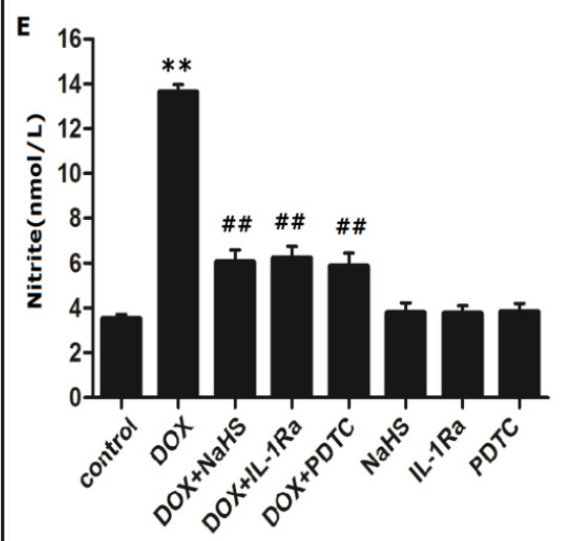

receptor in iNOS expression and NO production, the cells were co-treated with $20 \mathrm{ng} / \mathrm{ml} \mathrm{IL-1Ra} \mathrm{and} 5 \mu \mathrm{M}$ DOX for $24 \mathrm{~h}$. Data are shown as the mean \pm SE ( $N=3$ for the test of iNOS expression, $\mathrm{N}=5$ for the test of NO production). ${ }^{* *} \mathrm{P}<0.01$, compared with the control group; ${ }^{\# \#} \mathrm{P}<0.01$, compared with the DOX-treated group.

Fig. 4. IL-1 $\beta$ receptor antagonist and iNOS inhibitor ameliorate the DOX-induced cytotoxicity in H9c2 cells. H9c2 cells were co-cultured with $5 \mu \mathrm{M}$ DOX and $20 \mathrm{ng} / \mathrm{ml}$ IL-1Ra for $24 \mathrm{~h}$ or pretreated with $5 \mu \mathrm{M}$ L-canavanine(L-Can, an inhibitor of iNOS) for 60 min prior to exposure to DOX for $24 \mathrm{~h}$. Cell viability was measured using the CCK- 8 assay. The data are presented as the mean $\pm \mathrm{SE}(\mathrm{N}=5) .{ }^{* *} \mathrm{P}<0.01$, compared with the control group; \#\# $\mathrm{P}<0.01$, compared with the DOX-treated group. IL-1Ra, IL-1 $\beta$ receptor antagonist.

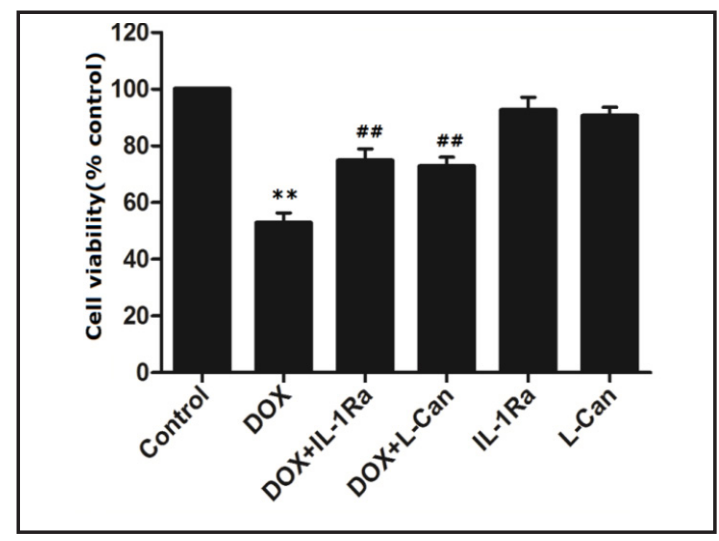

$I L-1 \beta$ receptors and iNOS are involved in the DOX-induced cytotoxicity in $H 9 c 2$ cells

We further clarify the roles of IL-1 $\beta$ receptor and iNOS in the DOX-induced cytotoxicity. As shown in Fig. 4, exposure of H9c2 cells to $5 \mu \mathrm{M}$ DOX for $24 \mathrm{~h}$ induced significant cytotoxicity, leading to a decrease in cell viability. However, the decreased cell viability was obviously diminished after the cells were co-treated with $20 \mathrm{ng} / \mathrm{ml} \mathrm{IL-1Ra}$ and $5 \mu \mathrm{M}$ DOX for $24 \mathrm{~h}$. 


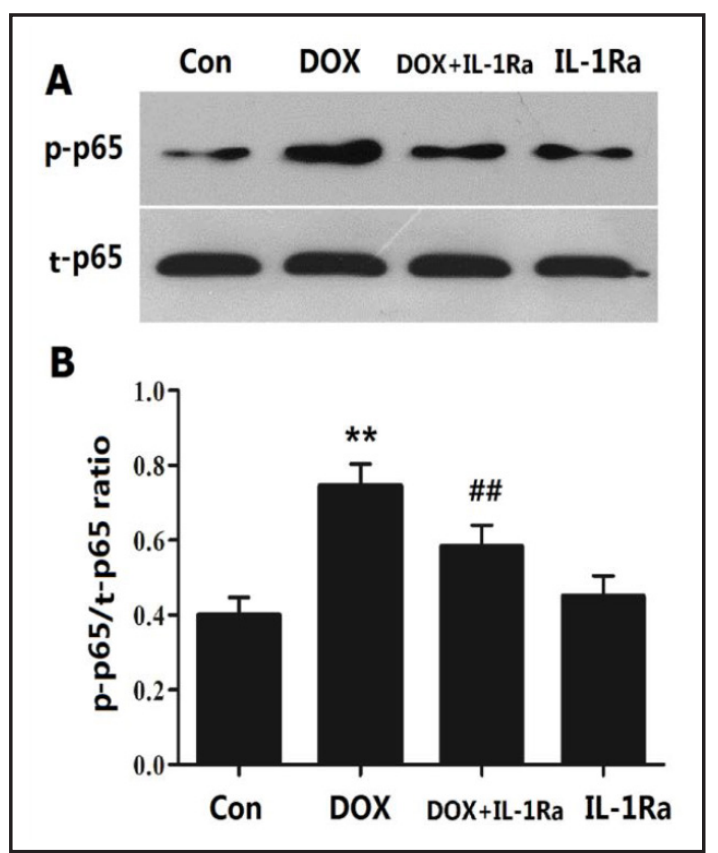

Fig. 5. IL-1 $\beta$ receptor antagonist blocks the DOX-induced activation of NF- $\kappa \mathrm{B}$ pathway in $\mathrm{H} 9 \mathrm{c} 2$ cells. $\mathrm{H} 9 \mathrm{c} 2$ cells were treated with $5 \mu \mathrm{M}$ DOX for $90 \mathrm{~min}$ in the absence or presence of co-culture with $20 \mathrm{ng} / \mathrm{ml}$ IL-1Ra for 90 min. (A)Expression of NF- $\kappa$ B p65 was tested by Western blot analysis and (B)Quantified by densitometric analysis with ImageJ 1.410 software. Data are shown as the mean $\pm \mathrm{SE}(\mathrm{N}=3)$. ${ }^{* *} \mathrm{P}<0.01$, compared with the control group; \#\# $\mathrm{P}<0.01$, compared with the DOX-treated group.

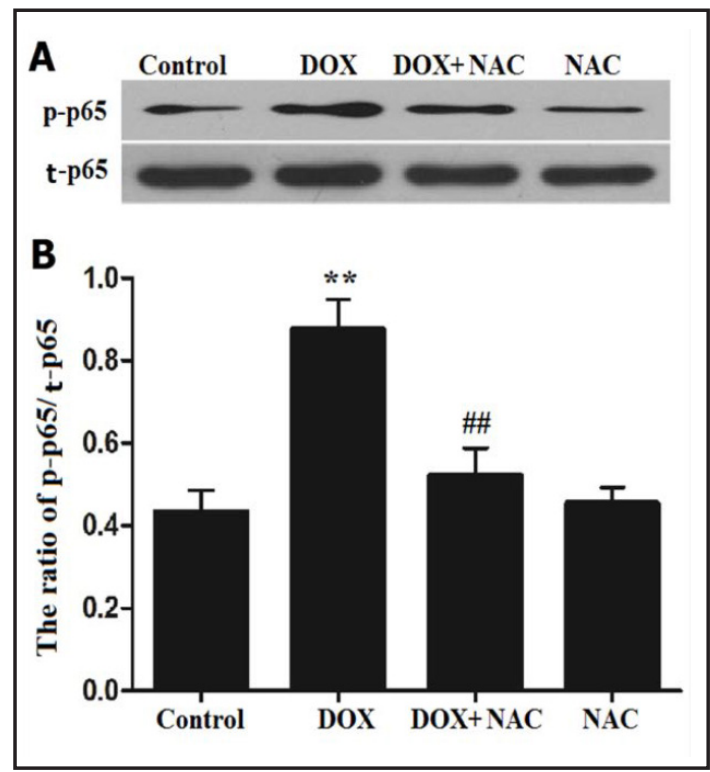

Fig. 6. ROS participate in the DOX-induced upregulation of phosphorylated NF- $\mathrm{kB}$ p65 expression in H9c2 cells. H9c2 cells were treated with $5 \mu \mathrm{M}$ DOX for $90 \mathrm{~min}$ in the absence or presence of pretreatment with $1000 \mu \mathrm{M}$ NAC for $60 \mathrm{~min}$ prior to exposure to DOX. (A)Expression of NF- $\mathrm{B}$ p65 was measured by Western blot analysis and (B)Quantified by densitometric analysis with ImageJ 1.410 software. Data was presented as the mean \pm SE $(\mathrm{N}=3)$. ${ }^{* *}$ $\mathrm{P}<0.01$, compared with the control group; ${ }^{\# \#} \mathrm{P}<0.01$, compared with the DOX-treated group.

In addition, when the cells were pretreated with $5 \mu \mathrm{M}$ L-canavanine (L-Can, an inhibitor of iNOS) for $60 \mathrm{~min}$ before exposure to DOX, the decreased cell viability was also markedly reduced. These results revealed that both IL-1 $\beta$ receptor and iNOS are implicated in the DOXinduced cytotoxicity in $\mathrm{H} 9 \mathrm{c} 2$ cells.

$I L-1 \beta$ receptors contribute to the DOX-induced upregulation of phosphorylated( $p$ ) NF- $\kappa B$ p65 expression in $\mathrm{H} 9 \mathrm{c} 2$ cells

Since the above results (Fig. 2) showed that the pretreatment with PDTC (a specific inhibitor of NF- $\kappa B$ ) inhibits the increased level of IL-1 $\beta$ by DOX, we further investigated the role of IL- $1 \beta$ receptors in the DOX-induced an increase in p-NF- $\kappa B$ p65 expression. As shown in Fig. 5, the exposure of cells to $5 \mu \mathrm{M}$ DOX for 90 min markedly upregulated the expression

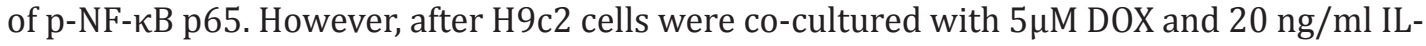
$1 \mathrm{Ra}$ for $90 \mathrm{~min}$, the enhanced expression level of p-NF- $\mathrm{KB}$ p 65 was significantly ameliorated, revealing that the activation of IL- $1 \beta$ receptors is implicated in an increase in expression of p-NF- $\kappa$ B p65 induced by DOX in H9c2 cells.

ROS scavenger reduces the DOX-induced an increase in phosphorylated NF- $\kappa B$ p65 expression in $\mathrm{H} 9 \mathrm{c} 2$ cells

Since we have demonstrated that exogenous $\mathrm{H}_{2} \mathrm{~S}$ depresses the DOX-induced ROS generation in H9c2 cells [10], this study further examined the role of antioxidation in the 
inhibitory effect of exogenous $\mathrm{H}_{2} \mathrm{~S}$ on the DOX-induced NF- $\kappa$ B activation in H9c2 cells. As shown in Fig. 6, after H9c2 cells were treated with $5 \mu \mathrm{M}$ DOX for $90 \mathrm{~min}$, the p-NF-кB p65 expression was markedly enhanced. However, when H9c2 cells were pretreated with 1000 $\mu \mathrm{M}$ NAC, a scavenger of ROS, for $60 \mathrm{~min}$ before exposure to DOX, the increased expression of p-NF- $\kappa B$ p 65 was dramatically ameliorated (Fig. 6), indicating involvement of ROS generation in the DOX-induced activation of NF- $\kappa \mathrm{B}$ pathway in $\mathrm{H} 9 \mathrm{c} 2$ cells.

\section{Discussion}

Here, we provide the novel findings including i) the protective effect of exogenous $\mathrm{H}_{2} \mathrm{~S}$ against the DOX-induced inflammation; ii) the involvement of inhibition of ROS-activated p38 MAPK/NF- $\kappa B$ pathway in the anti-inflammatory effect of exogenous $\mathrm{H}_{2} \mathrm{~S}$; and iii) the

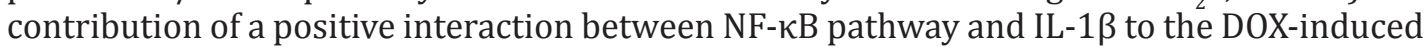
inflammation and cytotoxicity in the DOX-treated H9c2 cardiac cells.

DOX has been reported to induce a significant increase in the production of inflammatory markers, such as IL-1 $\beta[10,32]$. and IL-6 $[10,32,33]$, TNF- $\alpha[9,10,32,33]$ and cyclooxygenase-2 (COX-2) [34]. In agreement with these studies [9, 10, 32, 33, 34], DOX in our experimental model markedly elicited inflammatory response, as evidenced by an increase in the production of IL- $1 \beta$, IL- 6 and TNF- $\alpha$. Additionally, our data indicated that the activation of p38 MAPK/NF- $\kappa$ B pathway is necessary for the induction of DOX-induced inflammation, because pretreatment of H9c2 cells with either SB203580 (a specific inhibitor of p38 MAPK) or Si-p38 or PDTC (a specific inhibitor of NF- $\kappa B$ ) significantly reduced the increased levels of IL-1 $\beta$, IL- 6 and TNF- $\alpha$ by DOX, which is consistent with a more recent study [10].

IL-1 $\beta$ is an initiator cytokine and plays an important role in the regulation of the immune and inflammatory response [35]. For example, IL-1 $\beta$ has been shown to contribute to the DOX-induced increases in the levels of IL-6 and GCSF [32], and play an important role in the acute DOX-induced cardiotoxicity [36]. Recently, Zhu et al. reported that DOX treatment highly induces the expression of IL-1 $\beta$ and IL-1 type 1 receptor (IL-1R1) and that recombinant human IL-1 receptor antagonist (rhIL-1Ra) prevents from acute DOXinduced cardiotoxicity in mice, suggesting the involvment of IL-1 $\beta$ in the DOX-induced cardiotoxicity[36]. On the other hand, NF- $\kappa \mathrm{B}$ is a positive regulator of COX-2 expression in response to various cytokines and growth factors [37, 38], and participates in DOX-induced cardiomyocyte injury [14]. Thus, elucidating whether or not there is an interaction between IL-1 $\beta$ and NF- $\kappa B$ pathway may present opportunities to ameliorate the inflammatory consequences of DOX. The findings of this study demonstrated that IL-1Ra (IL-1 $\beta$ receptor antagonist) significantly blocks the DOX-induced phosphorylation of NF- $\kappa$ B p65 expression and cytotoxicity, suggesting the involvement of IL- $1 \beta$ receptor activation in the activation of NF- $\mathrm{KB}$ pathway and cytotoxicity induced by DOX in H9c2 cardiac cells. Combining with the above result that pretreatment with PDTC inhibits the DOX-induced an increase in IL$1 \beta$ level (Fig. 2), it was revealed that there is a positive interaction between NF- $\kappa B$ pathway and IL-1 $\beta$ during the development of inflammation and cytotoxicity induced by DOX. To further clarify the role of this interaction in the DOX-induced inflammatory response and cytotoxicity, We explored the effects of both IL-1 $\beta$ and NF- $\kappa$ B on their target genes, such as the pro-inflammatory mediator iNOS [39] that generates large quantities of NO.

Accumulating evidence reveals that NO may play diverse roles in cardiac functions and diseases. While basal production of NO (via constitutive NOS isoforms) modulates cardiomyocyte contractility and blood flow distribution [40], high levels of NO production (via iNOS) are associated with several cardiac diseases, including dilated cardiomyopathy and congestive heart failure [41]. The high concentration of NO may contribute to cardiomyocyte oxidative damage, apoptosis, and / or necrosis. Notably, the roles of iNOS and NO in the DOX-induced cardiotoxicity have attracted attention $[26,27,28]$. DOX significantly 
stimulates the expression of iNOS [26, 27] and NO production in H9c2 cells [27]. The iNOS inhibitor aminoguanidine ameliorates acute cardiomyopathy in the DOX-treated rats [28]. Interestingly, the expression of iNOS and NO production have been shown to be regulated by pro-inflammatory cytokines (such as IL-1 and TNF- $\alpha$ ) and NF- $\kappa B$ in several cell models [29, $30,31]$. However, it is unclear whether IL-1 $\beta$ and NF- $\kappa B$ modulate the expression of iNOS and NO production in the DOX-treated $\mathrm{H} 9 \mathrm{c} 2$ cells. In agreement with the previous studies $[26,27,28]$, the findings of this study showed that exposure of H9c2 cells to DOX markedly increased the expression of iNOS and NO production. Importantly, we found that IL-1Ra and PDTC obviously attenuated the increased expression of iNOS and NO production by DOX, suggesting that both IL- $1 \beta$ and NF- $\kappa B$ may play an important role in the stimulatory effects of DOX on the expression of iNOS and NO production. In addition, our results demonstrated that pretreatment of H9c2 cells with L-Can, an inhibitor of iNOS, markedly reduced the DOX-induced cytotoxicity, leading to an increase in cell viability. Our data is supported by a previous study [28]. Collectively, the findings of present study supported the notion that the positive interaction between NF- $\kappa B$ and IL- $1 \beta$ may be a critical mechanism responsible for the DOX-induced inflammatory response and cytotoxicity.

Significantly, this study demonstrated the potential anti-inflammatory effect of exogenous $\mathrm{H}_{2} \mathrm{~S}$ in the DOX-treated $\mathrm{H} 9 \mathrm{c} 2$ cells. To date, $\mathrm{H}_{2} \mathrm{~S}$ has been considered as a novel gasomolecule with cardioprotective effect. Endogenous $\mathrm{H}_{2} \mathrm{~S}$ can be synthesized in various mammalian tissues by four enzymes: cytathionine- $\beta$-synthase (CBS), cytathionine- $\gamma$ lyase (CSE), 3-mercaptopyruvate sulfurtransferase(3-MST) and cysteine lyase (CL), whose expressions are tissue specific. CBS is the predominant enzyme in the nervous system, liver and kidney, whereas CSE is mainly expressed in cardiovascular system and smooth muscle cells $[15,42]$. Recently, what is the change in endogenous $\mathrm{H}_{2} \mathrm{~S}$ level under the DOX treatment condition has attracted attention. In the DOX-treated rats, the $\mathrm{H}_{2} \mathrm{~S}$ levels in plasma and myocardium are markedly reduced [25]. We also demonstrated that exposure of H9c2 cardiac cells to DOX dramatically attenuates the expression and activity of CSE [7]. In addition, our further studies showed that exogenous $\mathrm{H}_{2} \mathrm{~S}$ offers protective effects, including anti-cytotoxicity, anti-apoptosis, anti-oxidative stress, and mitochondrial protection, against the DOX-induced insults in H9c2 cardiac cells $[7,10]$. Some of the mechanisms responsible for these protective effects may be associated with $\mathrm{H}_{2} \mathrm{~S}^{\prime}$ antioxidation (lowering ROS generation), inhibition of endoplasmic reticulum stress and p38 MAPK pathway [7, 10]. However, the effect of exogenous $\mathrm{H}_{2} \mathrm{~S}$ on the DOX-induced inflammation is unclear.

Since we have demonstrated the inhibitory effects of exogenous $\mathrm{H}_{2} \mathrm{~S}$ on the chemical hypoxia-induced inflammatory responses in HaCaT cells [22] and in PC12 cells [23]. These findings promote us to investigate whether or not exogenous $\mathrm{H}_{2} \mathrm{~S}$ protects $\mathrm{H} 9 \mathrm{c} 2$ cardiac cells against the DOX-induced inflammation. To our knowledge, the role of $\mathrm{H}_{2} \mathrm{~S}$ in inflammatory processes is controversial. It has reported that $\mathrm{H}_{2} \mathrm{~S}$ has a proinflammatory role in several animal models $[43,44,45,46]$. Contrarily, the beneficial effects of exogenous $\mathrm{H}_{2} \mathrm{~S}$ on inflammatory response have been indicated in several studies. For example, $\mathrm{H}_{2} \mathrm{~S}$ depresses IL-6 expression in rheumatoid arthritic fibroblast-like synoviocytes [47]. In the LPS-stimulated microglia and astrocytes, $\mathrm{H}_{2} \mathrm{~S}$ can reduce NO production and TNF- $\alpha$ secretion [24]. In the present study, we provided clear evidence that the pretreatment with NaHS (a $\mathrm{H}_{2} \mathrm{~S}$ donor) attenuates the DOX-induced cardiomyocyte inflammatory response, leading to a decrease in the production of IL-1 $\beta$, IL- 6 and TNF- $\alpha$. Our data are comparable with the previous studies [22, 23, 24,47]. Additionally, NaHS pretreatment reduced the increased expression of iNOS and NO production.

As we have demonstrated that the $338 \mathrm{MAPK} / \mathrm{NF}-\kappa \mathrm{B}$ pathway contributes to the DOX-induced inflammation in H9c2 cardiac cells [14], this study further explored the role of inhibition of p38 MAPK/NF- $\kappa \mathrm{B}$ pathway activation in the anti-inflammatory effect of exogenous $\mathrm{H}_{2} \mathrm{~S}$. Our results showed that the pretreatment of H9c2 cells with NaHS before exposure to DOX markedly inhibited the phosphorylation of p38 MAPK [10] and NF- $\mathrm{BB}$ p65 as well as nuclear translocation of NF- $\mathrm{BB}$ p65 (Fig. 1), suggesting the inhibitory effect of exogenous $\mathrm{H}_{2} \mathrm{~S}$ on the activation of $\mathrm{p} 38 \mathrm{MAPK} / \mathrm{NF}-\mathrm{\kappa B}$ pathway by DOX. Furthermore, similar 
to the anti-inflammatory effect of exogenous $\mathrm{H}_{2} \mathrm{~S}$, the pretreatment with either SB203580 or Si-p38 or PDTC markedly ameliorated the DOX-induced production of pro-inflammatory cytokines, such as IL-1 $\beta$, IL- 6 and TNF- $\alpha$, further revealing that the inhibition of p38 MAPK/ NF- $\kappa B$ pathway contributes to the inhibitory effect of exogenous $\mathrm{H}_{2} \mathrm{~S}$ on the inflammatory response induced by DOX. Several recent studies have shown that exogenous $\mathrm{H}_{2} \mathrm{~S}$ attenuates the chemical hypoxia-induced [23] or LPS-induced [24] inflammation by inhibition of p38 MAPK pathway. Additionally, Yang et al. reported that the inhibition of ROS/ NF- $\kappa B$ / COX-2 pathway participates in the anti-inflammation of $\mathrm{H}_{2} \mathrm{~S}$ in chemical hypoxia-treated HaCaT cells [22]. These studies [22, 23, 24] support our results. On the other hand, this study demonstrated that another mechanism underlying the anti-inflammatory effect of exogenous $\mathrm{H}_{2} \mathrm{~S}$ may be associated with its antioxidation, because NAC, a ROS scavenger, has an inhibitory effect similar to $\mathrm{H}_{2} \mathrm{~S}$ on the phosphorylation of NF- $\kappa$ B p65 by DOX.

In conclusion,this study provided the novel mechanistic evidence that exogenous $\mathrm{H}_{2} \mathrm{~S}$ attenuates the DOX-induced inflammation and cytotoxicity through inhibition of the p38 MAPK/NF- $\kappa B$ pathway in H9c2 cardiac cells. The findings of this study and our recent studies $[7,10]$ provide the clues for $\mathrm{H}_{2} \mathrm{~S}$ treatment to DOX cardiotoxicity, such as anti-inflammation, anti-cytotoxicity, anti-apoptosis, anti-oxidative stress, anti-endoplasmic stress, and mitochondrial protection. However, more studies are required, such as animal experiment in vivo and the effects of exogenous $\mathrm{H}_{2} \mathrm{~S}$ on DOX-treated different cells or organs.

\section{Acknowledgements}

This study was supported by the Science and Technology Planing Project of Guangdong of China (2012B031800358, 2012A080202020), and Science and Technology Competitive Program supported by Zhanjiang Financial Foundation (no. 79, Zhanjiang 2011).

\section{References}

1 Ma Y, Kurtyka CA, Boyapalle S, Sung SS, Lawrence H, Guida W, Cress WD: A small-molecule E2F inhibitor blocks growth in a melanoma culture model. Cancer Res 2008;68:6292-6299.

- Li L, Takemura G, Li Y, Miyata S, Esaki M, Okada H, Kanamori H, Khai NC, Maruyama R, Ogino A, Minatoguchi S, Fujiwara T, Fujiwara H: Preventive effect of erythropoietin on cardiac dysfunction in doxorubicin-induced cardiomyopathy. Circulation 2006;113:535-543.

3 Muggia FM, Green MD: New anthracycline antitumor antibiotics. Crit Rev Oncol Hematol 1991;11:43-64.

4 Scully RE, Lipshultz SE: Anthracycline cardiotoxicity in long-term survivors of childhood cancer. Cardiovasc Toxicol 2007; 7:122-128.

5 Hrdina R, Gersl V, Klimtova I, Simunek T, Machackova J, Adamcova M: Anthracycline-induced cardiotoxicity. Acta Medica (Hradec Kralove) 2000;43:75-82.

6 Minotti G, Menna P, Salvatorelli E, Cairo G, Gianni L: Anthracyclines: Molecular advances and pharmacologic developments in antitumor activity and cardiotoxicity. Pharmacol Rev 2004;56:185-229.

7 Wang XY, Yang CT, Zheng DD, Mo LQ, Lan AP, Yang ZL, Hu F, Chen PX, Liao XX, Feng JQ: Hydrogen sulfide protects $\mathrm{H} 9 \mathrm{c} 2$ cells against doxorubicin-induced cardiotoxicity through inhibition of endoplasmic reticulum stress. Mol Cell Biochem 2012;363:419-426.

8 Chiosi E, Spina A, Sorrentino A, Romano M, Sorvillo L, Senatore G, D'Auria R, Abbruzzese A, Caraglia M, Naviglio S, Illiano G: Change in TNF- $\alpha$ receptor expression is a relevant event in doxorubicin-induced H9c2 cardiomyocyte cell death. J Interferon Cytokine Res 2007;27:589-597.

-9 Riad A, Bien S, Westermann D, Becher PM, Loya K, Landmesser U, Kroemer HK, Schultheiss HP, Tschope C: Pretreatment with statin attenuates the cardiotoxicity of doxorubicin in mice. Cancer Res 2009;69:695699.

10 Guo R, Lin J, Xu W, Shen N, Mo L, Zhang C, Feng J: Hydrogen sulfide attenuates doxorubicin-induced cardiotoxicity by inhibition of the p38 MAPK pathway in H9c2 cells. Int J Mol Med 2013;31:644-650. 
11 Bien S, Riad A, Ritter CA, Gratz M, Olshausen F, Westermann D, Grube M, Krieg T, Ciecholewski S, Felix SB, Staudt A, Schultheiss HP, Ewert R, Volker U, Tschope C, Kroemer HK: The endothelin receptor blocker bosentan inhibits doxorubicin-induced cardiomyopathy. Cancer Res 2007;67:10428-10435.

12 Sheng Z, Knowlton K, Chen J, Hoshijima M, Brown JH, Chien KR: Cardiotrophin 1 (CT-1) inhibition of cardiac myocyte apoptosis via a mitogen-activated protein kinase-dependent pathway. Divergence from downstream CT-1 signals for myocardial cell hypertrophy. J Biol Chem 1997;272:5783-5791.

13 Sugden PH, Clerk A: "Stress-responsive" mitogen-activated protein kinases (c-jun n-terminal kinases and p38 mitogen-activated protein kinases) in the myocardium. Circ Res 1998;83:345-352.

14 Guo R, Xu W, Lin J, Mo L, Hua X, Chen P, Wu K, Zheng D, Feng J: Activation of the p38 MAPK/NF- $\mathrm{BB}$ pathway contributes to doxorubicin-induced inflammation and cytotoxicity in H9c2 cardiac cells. Mol Med Rep 2013;8:603-608.

15 Lowicka E, Beltowski J: Hydrogen sulfide $\left(\mathrm{H}_{2} \mathrm{~S}\right)$ - the third gas of interest for pharmacologists. Pharmacol Rep 2007;59:4-24.

16 Moore PK, Bhatia M, Moochhala S: Hydrogen sulfide: From the smell of the past to the mediator of the future? Trends Pharmacol Sci 2003;24:609-611.

17 El-Seweidy MM, Sadik NA, Shaker OG: Role of sulfurous mineral water and sodium hydrosulfide as potent inhibitors of fibrosis in the heart of diabetic rats. Arch Biochem Biophys 2011;506:48-57.

18 Dong XB, Yang CT, Zheng DD, Mo LQ, Wang XY, Lan AP, Hu F, Chen PX, Feng JQ Zhang MF, Liao XX: Inhibition of ROS-activated ERK1/2 pathway contributes to the protection of $\mathrm{H}_{2} \mathrm{~S}$ against chemical hypoxia-induced injury in H9c2 cells. Mol Cell Biochem 2012;362:149-157.

19 Yang Z, Yang C, Xiao L, Liao X, Lan A, Wang X, Guo R, Chen P, Hu C, Feng J: Novel insights into the role of HSP90 in cytoprotection of $\mathrm{H}_{2} \mathrm{~S}$ against chemical hypoxia-induced injury in H9c2 cardiac myocytes. Int J Mol Med 2011;28:397-403.

20 Chen SL, Yang CT, Yang ZL, Guo RX, Meng JL, Cui Y, Lan AP, Chen PX, Feng JQ: Hydrogen sulphide protects H9c2 cells against chemical hypoxia-induced injury. Clin Exp Pharmacol Physiol 2010;37:316-321.

21 Calvert JW, Jha S, Gundewar S, Elrod JW, Ramachandran A, Pattillo CB, Kevil CG, Lefer DJ: Hydrogen sulfide mediates cardioprotection through Nrf2 signaling. Circ Res 2009;105:365-374.

22 Yang C, Yang Z, Zhang M, Dong Q, Wang X, Lan A, Zeng F, Chen P, Wang C, Feng J: Hydrogen sulfide protects against chemical hypoxia-induced cytotoxicity and inflammation in hacat cells through inhibition of ROS/ NF-kappab/COX-2 pathway. PloS one 2011;6:e21971.

23 Lan A, Xu W, Zhang H, Hua X, Zheng D, Guo R, Shen N, Hu F, Feng J, Liu D: Inhibition of ROS-activated p38 MAPK pathway is involved in the protective effect of $\mathrm{H}_{2} \mathrm{~S}$ against chemical hypoxia-induced inflammation in PC12 cells. Neurochem Res 2013;38:1454-1466.

-24 Hu LF, Wong PT, Moore PK, Bian JS: Hydrogen sulfide attenuates lipopolysaccharide-induced inflammation by inhibition of p38 mitogen-activated protein kinase in microglia. J Neurochem 2007;100:1121-1128.

25 Su YW, Liang C, Jin HF, Tang XY, Han W, Chai LJ, Zhang CY, Geng B, Tang CS, Du JB: Hydrogen sulfide regulates cardiac function and structure in adriamycin-induced cardiomyopathy. Circ J 2009;73:741-749.

26 Liu B, Li H, Qu H, Sun B: Nitric oxide synthase expressions in adr-induced cardiomyopathy in rats. J Biochem Mol Biol 2006;39:759-765.

27 Aldieri E, Bergandi L, Riganti C, Costamagna C, Bosia A, Ghigo D: Doxorubicin induces an increase of nitric oxide synthesis in rat cardiac cells that is inhibited by iron supplementation. Toxicol Appl Pharmacol 2002;185:85-90.

28 Cigremis Y, Parlakpinar H, Polat A, Colak C, Ozturk F, Sahna E, Ermis N, Acet A: Beneficial role of aminoguanidine on acute cardiomyopathy related to doxorubicin-treatment. Mol Cell Biochem 2006;285:149-154.

29 Madonna R, Di Napoli P, Massaro M, Grilli A, Felaco M, De Caterina A, Tang D, De Caterina R, Geng YJ: Simvastatin attenuates expression of cytokine-inducible nitric-oxide synthase in embryonic cardiac myoblasts. J Biol Chem 2005;280:13503-13511.

30 Birks EJ, Yacoub MH, Burton PS, Owen V, Pomerance A, O'Halloran A, Banner NR, Khaghani A, Latif N: Activation of apoptotic and inflammatory pathways in dysfunctional donor hearts. Transplantation 2000;70:1498-1506.

-31 Teng X, Zhang H, Snead C, Catravas JD: Molecular mechanisms of inos induction by IL-1 beta and IFN- $\gamma$ in rat aortic smooth muscle cells. Am J Physiol Cell Physiol 2002;282:C144-152. 


\section{Cellular Physiology $\quad$ Cell Physiol Biochem 2013;32:1668-1680}

and Biochemistry

Guo et al:: Cardioprotection of Hydrogen Sulfide against DOX via Inhibiting p38MAPK/ NFkB Pathway

32 Sauter KA, Wood LJ, Wong J, Iordanov M, Magun BE: Doxorubicin and daunorubicin induce processing and release of interleukin-1 $\beta$ through activation of the NLRP3 inflammasome. Cancer Biol Ther 2011;11:10081016.

-33 Zordoky BN, Anwar-Mohamed A, Aboutabl ME, El-Kadi AO: Acute doxorubicin toxicity differentially alters cytochrome p450 expression and arachidonic acid metabolism in rat kidney and liver. Drug Metab Dispos 2011;39:1440-1450.

34 Huang CC, Chen PC, Huang CW, Yu J: Aristolochic acid induces heart failure in zebrafish embryos that is mediated by inflammation. Toxicol Sci 2007;100:486-494. Dinarello CA: Il-1: Discoveries, controversies and future directions. Eur J Immunol 2010;40:599-606.

Zhu J, Zhang J, Xiang D, Zhang Z, Zhang L, Wu M, Zhu S, Zhang R, Han W: Recombinant human interleukin-1 receptor antagonist protects mice against acute doxorubicin-induced cardiotoxicity. Eur J Pharmacol 2010;643:247-253.

37 Huang CY, Fujimura M, Noshita N, Chang YY, Chan PH: SOD1 down-regulates NF- $\kappa B$ and c-Myc expression in mice after transient focal cerebral ischemia. J Cereb Blood Flow Metab 2001;21:163-173.

- 38 Kang YJ, Wingerd BA, Arakawa T, Smith WL: Cyclooxygenase-2 gene transcription in a macrophage model of inflammation. J Immunol 2006;177:8111-8122.

39 Karin M, Ben-Neriah Y: Phosphorylation meets ubiquitination: The control of NF- $\kappa$ B activity. Annu Rev Immunol 2000;18:621-663.

- 40 Varin R, Mulder P, Richard V, Tamion F, Devaux C, Henry JP, Lallemand F, Lerebours G, Thuillez C: Exercise improves flow-mediated vasodilatation of skeletal muscle arteries in rats with chronic heart failure. Role of nitric oxide, prostanoids, and oxidant stress. Circulation 1999;99:2951-2957.

41 Haywood GA, Tsao PS, von der Leyen HE, Mann MJ, Keeling PJ, Trindade PT, Lewis NP, Byrne CD, Rickenbacher PR, Bishopric NH, Cooke JP, McKenna WJ, Fowler MB: Expression of inducible nitric oxide synthase in human heart failure. Circulation 1996;93:1087-1094.

42 Wang R: Two's company, three's a crowd: Can $\mathrm{H}_{2} \mathrm{~S}$ be the third endogenous gaseous transmitter? FASEB J 2002;16:1792-1798.

43 Li L, Bhatia M, Moore PK: Hydrogen sulphide-a novel mediator of inflammation? Curr Opin Pharmacol 2006;6:125-129.

44 Zhang H, Zhi L, Moore PK, Bhatia M: Role of hydrogen sulfide in cecal ligation and puncture-induced sepsis in the mouse. Curr Opin Pharmacol 2006;290:L1193-1201.

45 Mok YY, Atan MS, Yoke Ping C, Zhong Jing W, Bhatia M, Moochhala S, Moore PK: Role of hydrogen sulphide in haemorrhagic shock in the rat: Protective effect of inhibitors of hydrogen sulphide biosynthesis. Br J Pharmacol 2004;143:881-889.

46 Bhatia M, Wong FL, Fu D, Lau HY, Moochhala SM, Moore PK: Role of hydrogen sulfide in acute pancreatitis and associated lung injury. FASEB J 2005;19:623-625.

47 Kloesch B, Liszt M, Broell J: $\mathrm{H}_{2} \mathrm{~S}$ transiently blocks IL-6 expression in rheumatoid arthritic fibroblast-like synoviocytes and deactivates p44/42 mitogen-activated protein kinase. Cell Biol Int 2010;34:477-484. 